\title{
Implementasi Nilai-nilai Karakter Di Madrasah Ibtidaiyah Melalui Konsep ESQ Learning
}

\author{
Mohammad Rofiq ${ }^{1}$ \\ ${ }^{1}$ Pendidikan Guru Madrasah Ibtidaiyah, UIN Walisongo, Semarang, Indonesia \\ *Corresponding author: mrofiq@walisongo.ac.id
}

\begin{abstract}
Abstrak
Penelitian ini membahas nilai-nilai karakter yang terkandung dalam konsep ESQ learning, kemudian direlevansikan pada pendidikan karakter di Madrasah Ibtidaiyah. Kajiannyadilatar belakangi oleh semakin maraknya pendidikan karakter yang perlu diberikan nilai karakter lebih dalam proses pembelajaran agar menghasilkan output peserta didik yang berakhlaqul karimah. Penelitian ini dimaksudkan untuk menjawab permasalahan: (1) Bagaimana konsep pendidikan karakter di Madrasah Ibtidaiyah? (2) Bagaimana nilai-nilai karakter dalam konsep ESQ learning dan relevansinya dalam pendidikan karakter di Madrasah Ibtidaiyah? Permasalahan tersebut dibahas melalui metodologi penelitian kualitatif. Kajian ini menunjukkan bahwa (1) Konsep pendidikan karakter di Madrasah Ibtidaiyah sama dengan pendidikan akhlak, yakni pendidikan yang bertujuan untuk membentuk perilaku manusia sesuai dengan ajaran Islam, berlandaskan al-Qur'an dan Hadits. (2) Sesuai dengan konsep ESQ learning, maka nilai-nilai karakter masing-masing terkandung dalam sumber nilai yang berlaku dalam pranata kehidupan manusia, yaitu nilai Ilahiyah dan Insaniyah. Temuan tersebut memberikan acuan bagi lembaga pendidikan tentang pendidikan karakter dari tokoh atau pakar dalam bingkai ilmu ESQ. Kemudian dapat menjadi acuan para orangtua atau pendidik dalam mendidik anak, agar mengacu pada konsep pendidikan yang berkarakter, dengan cara yang benar dan berdasarkan pada ajaran Islam.
\end{abstract}

Kata Kunci: Pendidikan Karakter, ESQ Learning, Pendidikan Dasar

\section{PENDAHULUAN}

Sekolah telah menjadi lembaga pendidikan sebagai media berbenah diri dan membentuk nalar berpikir yang kuat dengan ilmu pengetahuan dan teknologi serta membentuk karakter peserta didik dengan nilai-nilai luhur. Sekolah bertanggung jawab menanamkan pengetahuan-pengetahuan baru yang reformatif dan transformatif dalam membangun bang sayang maju dan berkualitas. Sekolah juga bertanggung jawab mentransformasikan nilai-nilai luhur kepada siswa. Dengan sekolah, umat manusia yang berperadaban dan beragama mendidik anak-anaknya untuk menjadi anak yang memiliki kecerdasan intelektual, emosional, dan spiritual yang tinggi sebagai bekal untuk melanjutkan dan memperjuangkan agamanya. Di sekolah berlangsung proses 
transformasi nilai-nilai luhur melalui pendidikan karakter. Pendidikan karakter merupakan kata kunci dari proses transformasi nilai-nilai luhur di sekolah. ${ }^{1}$

Pendidikan karakter bukanlah sebuah gagasan baru. Sebetulnya pendidikan karakter sama tuanya dengan pendidikan itu sendiri. Sepanjang sejarah, di negaranegara seluruh dunia, pendidikan memiliki dua tujuan besar: membantu anak-anak menjadi pintar dan membantu mereka menjadi baik. Menyadari pintar dan baik tidaklah sama, sejak zaman Plato masyarakat yang bijak telah menjadikan pendidikan karakter sebagai tujuan sekolah. Mereka telah memberikan pendidikan karakter yang dibarengkan dengan pendidikan intelektual, kesusilaan, literasi, serta budi pekerti dan pengetahuan. $^{2}$

Pola yang tepat dalam mendidik anak pada tahun-tahun pertama memainkan peranan yang sangat penting bagi pengaruh pembentukannya yang bersifat mental dan sosial. Dengan kata lain yang lebih kompleks, hal itu sangat berpengaruh bagi pembentukan kepribadiannya. ${ }^{3}$

Menurut Thomas Lickona, pada dasarnya pendidikan memiliki dua tujuan, yaitu membimbing para generasi muda untuk menjadi cerdas dan memiliki perilaku berbudi. Kita semua tahu bahwa kata "cerdas" dan "baik" bukanlah dua kata yang sama. Para pemangku kebijakan sejak zaman Plato telah membuat suatu kebijakan mengenai pendidikan moral yang secara sengaja dibuat sebagai bagian utama dari pendidikan sekolah. ${ }^{4}$ Oleh karena itu, perlu adanya sebuah inovasi agar kedua kata tersebut dapat diseimbangkan untuk membentuk sebuah pendidikan yang menghasilkan peserta didik yang tidak hanya cerdas dalam pengetahuan, tetapi baik pula perilakukanya.

Selama ini banyak orang menganggap jika seseorang memiliki tingkat kecerdasan intelektual (IQ) yang tinggi, maka orang tersebut memiliki peluang untuk meraih kesuksesan yang lebih besar dibanding dengan orang lain. Pada kenyataannya banyak contoh di sekitar kita membuktikan bahwa orang yang memiliki kecerdasan otak saja, atau banyak memiliki gelar yang tinggi belum tentu sukses berkiprah di dunia pekerjaan. Bahkan seringkali yang berpendidikan formal lebih rendah ternyata banyak yang berhasil. Saat ini begitu banyak orang-orang yang berpendidikan dan tampak begitu menjanjikan, namun kariernya mandek atau lebih buruk lagi tersingkir. ${ }^{5}$

Telah ditemukan $\mathrm{Q}$ jenis ketiga yang posisinya mengalahkan dominasi faktor keberhasilan EQ, yaitu kecerdasan spiritual (spiritual quotient) yang sering disebut SQ. menurut Danah Zohar dan Ian Marsall kecerdasan spiritual adalah kecerdasan untuk menghadapi persoalan makna, yaitu kecerdasan untuk menempatkan perilaku dan

\footnotetext{
${ }^{1}$ N.A Wiyani, Membumikan Pendidikan Karakter di SD; Konsep, Praktik dan Strategi, (Yogyakarta: AR-Ruzz Media, 2013), hlm. 12.

${ }^{2}$ T. Lickona, Pendidikan Karakter Panduan Lengkap Mendidik Siswa Menjadi Pintar dan Baik, (Jakarta: Bumi Aksara, 2013), hlm. 6-7.

${ }^{3}$ T. Lickona, Educating for Character. Mendidik untuk Membentuk Karakter, (Jakarta: Bumi Aksara, 2012), hlm. 7.

${ }^{4}$ T. Lickona, Pendidikan Karakter..., hlm. 6.

${ }^{5}$ A.G. Agustian, Rahasia Sukses Membangun Kecerdasan Emosi dan Spiritual ESQ (Emotional Spiritual Quotiont): Berdasarkan 6 Rukun Iman dan 5 Rukun Islam, (Jakarta: Arga Wijaya Persada, 2001), hlm. 56.
} 
hidup kita dalam konteks makna yang lebih luas dan kaya, kecerdasan untuk menilai bahwa tindakan atau jalan hidup seseorang lebih bermakna dibandingkan dengan yang lain. SQ adalah landasan yang diperlukan untuk memfungsikan IQ dan EQ secara efektif. Bahkan SQ merupakan kecerdasan tertinggi kita. ${ }^{6}$

Pendidikan dalam pembentukan sikap (emosi) dan perilaku anak tidak harus selalu berorientasi pada kecerdasan intelektual (intellectual quotient), akan tetapi harus berorientasi juga pada upaya penumbuhkembangan atau meningkatkan emotional quotient dan spiritual quotient pada diri anak.

Pendidikan di Indonesia selama ini, terlalu menekankan arti penting akademik, kecerdasan otak atau IQ saja. Mulai dari tingkat sekolah dasar, sampai kebangku kuliah, jarang sekali ditemukan pendidikan tentang kecerdasan emosi yang mengajarkan tentang: keadilan, integritas, kejujuran, komitmen, visi, kreativitas, ketahanan mental, kebijaksanaan, prinsip kepercayaan, penguasaan diri atau sinergi, padahal justru inilah hal yang terpenting. Meskipun mereka mempunyai pendidikan yang tinggi dan gelargelar di depan atau belakang namanya, mereka hanya mengandalkan logika, namun mengabaikan suara hati yang sebenarnya mampu memberikan informasi-informasi maha penting untuk mencapai keberhasilan. ${ }^{7}$

Kecerdasan emosi memegang peranan yang sangat penting dalam mencapai keberhasilan disegala bidang. Menurut Robert K. Cooper, hati mengaktifkan nilai-nilai kita yang paling dalam, mengubah nyadari sesuatu yang kita pikir menjadi sesuatu yang kita jalani. Hati tahu hal-hal yang tidak, atau tidak dapat, diketahui oleh pikiran. Hati adalah sumber energi dan perasaan mendalam yang menurut kita belajar, menciptakan kerjasama, memimpin dan melayani. ${ }^{8}$

Berdasarkan uraian tersebut di atas, maka dalam pembahasan ini penulis mencoba menguraikan nilai-nilai Pendidikan Karakter dalam konsep ESQ learning serta relevansinya dengan pendidikan di Madrasah Ibtidaiyah. Fokus masalah yang hendak dikaji dalam penelitian ini terformulasi dalam pertanyaan sebagai berikut:

1. Bagaimana pendidikan karakter di Madrasah Ibtidaiyah?

2. Bagaimana implementasi nilai-nilai pendidikan karakter dalam konsep ESQ learning di Madrasah Ibtidaiyah?

\section{METODE PENELITIAN}

Secara operasional, metode yang digunakan dalam penelitian ini adalah sebagai berikut:

\section{Jenis dan Pendekatan Penelitian}

Pendekatan yang digunakan dalam penelitian ini adalah pendekatan kualitatif yaitu salah satu prosedur penelitian yang menghasilkan data deskriptif berupa ucapan

\footnotetext{
${ }^{6}$ A.G. Agustian, Rahasia Sukses Membangun ..., hlm. 57.

${ }^{7}$ Ibid., hlm. xiii.

${ }^{8}$ Ibid., hlm. iii.
} 
atau tulisan dan perilaku orang-orang yang diamati. ${ }^{9}$ Auebar candsil verstein mengatakan bahwa "qualitative research is research that in volves analyzing and interpreting text sandinter views in order todiscover meaning ful patterns descriptive of a particular phenomenon". ${ }^{10}$ Penelitian kualitatif adalah penelitian yang melakukan analisis dan interpretasi teks dan hasil interview dengan tujuan untuk menemukan makna dari suatu fenomena. Penelitian ini termasuk jenis penelitian kepustakaan (library research), yaitu serangkaian kegiatan yang berkenaan dengan metode pengumpulan data pustaka, membaca dan mencatat serta mengolah bahan penelitian. ${ }^{11}$

Secara kualititif, peneliti melakukan observasi disejumlah Madrasah Ibtidaiyah. Di bawah kementerian agama RI, maka dengan menggunakan satu atau dua Madrasah Ibtidaiyah saja sudah mewakili semua kurikulum yang ada di madrasah ibtidaiyah seluruh Indonesia. Peneliti juga melakukan analisis dokumen dari literatur yang membahas ESQ dan diasosiasikan dengan kurikulum yang ada di Madrasah Ibtidaiyah.

\section{Teknik Pengumpulan Data}

Teknik yang dipergunakan untuk memperoleh data dalam penelitian ini menggunakan beberapa Teknik observasi, wawancara, dan studi dokumentasi.

1) Observasi: Teknik observasi yang digunakan adalah observasi partisipasi pasif, artinya dalam hal ini peneliti datang di tempat kegiatan orang yang diamati, tetapi tidak ikut terlibat dalam kegiatan tersebut. ${ }^{12}$ Observasi yang dilakukan peneliti dilaksanakan dibeberapa Madrasah Ibtidaiyah.

2) Wawancara dilakukan peneliti untuk memberikan konfirmasi dan penguatan terhadap objek yang diteliti. Peneliti melakukan wawancara dengan guru-guru Madrasah Ibtidaiyah. Wawancara yang digunakan adalah wawancara terstruktur.

3) Studi dokumentasi, Studi dokumentasi adalah suatu metode untuk mencari data mengenai hal-hal atau variabel-variabel yang meliputi beberapa catatan, transkrip, buku, surat kabar, majalah, prasasti, notulen, rapat, agenda, dan sebagainya. ${ }^{13}$ Peneliti menganalisis beberapa literatur yang berkaitan dengan ESQ dan kurikulum Madrasah Ibtidaiyah.

Peneliti melakukan pengumpulan data secara triangulasi, yaitu memadukan data-data yang dikumpulkan dari observasi, wawancara, dan analisis dokumen.

\section{Teknik Analisis Data}

Sebelum membahas metode analisis data dalam skripsi ini akan diterangkan pengertian analisis data terlebih dahulu. Yang dimaksud dengan analisis data adalah suatu proses mengatur urutan data, mengorganisasikannya ke dalam suatu pola, kategori, dan satuan uraian dasar. ${ }^{14}$ Jadi, analisis data adalah hasil dari pengamatan-pengamatan atas

${ }^{9}$ J. Soewadji, Pengantar Metodologi Penelitian, (Jakarta: Mitra Wacana Media, 2012), hlm. 52.

${ }^{10}$ C. Auerbach \& L. B. Silverstein, Qualitative Data: an Introduction to coding and analysis, (Vol. 21), NYU Press, 2003.

${ }^{11}$ M. Zed, Metode Penelitian Kepustakaan, (Yayasan Obor Indonesia, 2004), hlm. 3.

${ }^{12}$ S. Sugiono, Metode Penelitian Kualitatif, (Bandung: Alfabeta, 2013), hlm. 108 .

${ }^{13}$ A. Suharsimi, Prosedur Penelitian suatu Pendekatan Praktek, (Jakarta: Rineka Cipta, 2006), hlm. 206.

${ }^{14}$ J. M. Lexy, Metodologi Penelitian Kualitatif, (Bandung: Remaja Rosdakarya, 2002), hlm. 208. 
beberapa yang dikumpulkan dan untuk kemudian dapat disimpulkan hasil dari pengamatan tersebut. Analisis data dilakukan dengan mengorganisasikan data, menjabarkannya ke dalam unit-unit, melakukan sintesa, menyusun ke dalam pola, memilih mana yang penting dan yang akan dipelajari, dan membuat kesimpulan.

Metode-metode yang digunakan dalam menganalisis data adalah sebagai berikut:

Metode Deskriptif yaitu suatu sistem penulisan dengan kata-kata, atau gambar yang berisi kutipan-kutipan data untuk memberi gambaran penyajian laporan tersebut. ${ }^{15}$ Metode ini terutama digunakan untuk menjelaskan tentang konsep ESQ, dalam kaitannya dengan pendidikan karakter di Madrasah Ibtidaiyah.

Metode Content Analisis yaitu suatu analisis mendalam yang dapat menggunakan teknik kuantitatif maupun kualitatif terhadap pesan-pesan menggunakan metode ilmiah dan tidak terbatas pada jenis-jenis variabel yang dapat diuku ratau konteks tempat pesanpesan diciptakan atau disajikan. Analisis isi kualitatif sebagaimana disajikan di sini, terdiri atas sekumpulan teknik untuk analisis teks secara sistematis. ${ }^{16}$ Artinya, dari semua data yang telah dianalisis harus menyajikan generalisasi, yang temuannya haruslah mempunyai sumbangan teoritik.

\section{HASIL DAN PEMBAHASAN}

\section{A. Konsep Dasar Pendidikan Karakter di Madrasah Ibtidaiyah \\ 1. Pengertian Pendidikan Karakter}

Pendidikan merupakan upaya untuk mengembangkan ranah kognitif, afektif, dan psikomotorik. Muara ranah kognitif adalah tumbuh dan berkembangnya kecerdasan dan kemampuan intelektual akademik. Ranah afektif bermuara pada terbentuknya karakter kepribadian. Dan ranah psikomotorik akan bermuara pada keterampilan vokasional dan perilaku. ${ }^{17}$

Berdasarkan pengertian pendidikan yang telah diuraikan, maka dapat dipahami bahwa pendidikan adalah suatu usaha yang dilakukan dengan penuh kesadaran dan terkonsep serta terencana untuk memberikan pembinaan dan pembimbingan pada peserta didik (anak-anak). Yang mana bimbingan dan pembinaan tersebut tidak hanya berorientasi pada daya pikir (intelektual) saja, akan tetapi juga pada segi emosional yang dengan pembinaan dan bimbingan akan dapat membawa perubahan pada arah yang lebih positif.

Karakter (character) adalah watak, perangai, sifat dasar yang khas, satu sifat atau kualitas yang tetap terus menerus dan kekal yang dapat dijadikan ciri untuk mengidentifikasi seorang pribadi. Ia disebabkan oleh bakat pembawaan dan sifat-sifat hereditas sejak lahir dan sebagian disebabkan oleh pengaruh lingkungan. Ia berkemungkinan untuk dapat dididik. Elemen karakter terdiri atas

${ }^{15}$ L. J. Moleong, Metodologi Penelitian Kualitatif edisi revisi, (Bandung: PT. Remaja Rosdakarya, 2007), hlm. 11.

${ }^{16}$ A. D. Emzir, Metodologi Penelitian Kualitatif, (Jakarta: Raja Wali Press, 2011), hlm. 283-284.

${ }^{17}$ D. Damayanti, Panduan Implementasi Pendidikan Karakter di Sekolah, (Yogyakarta: Araska, 2014), hlm. 9. 
dorongan-dorongan, insting, refleks-refleks, kebiasaan-kebiasaan, kecenderungankecenderungan, organ perasaan, emosi, sentimen, minat, kebajikan dan dosa, serta kemauan. ${ }^{18}$

Menurut Kemendiknas, karakter adalah watak, tabiat, akhlaq, atau kepribadian seseorang yang terbentuk dari hasil internalisasi berbagai kebajikan yang diyakini dan digunakan sebagai landasan untuk cara pandang, berpikir, bersikap dan bertindak. Kebajikan terdiri atas sejumlah nilai, moral dan norma, seperti jujur, berani bertindak, dapat dipercaya, dan hormat kepada orang lain. Interaksi seseorang dengan orang lain menumbuhkan karakter masyarakat dan karakter bangsa. Karakter sering dikaitkan dengan kepribadian, sehingga pembentukan karakter juga dihubungkan dengan pembentukan kepribadian. ${ }^{19}$

Seorang filsuf Yunani bernama Aristoteles mendefinisikan karakter yang baik sebagai kehidupan dengan melakukan tindakan-tindakan yang benar sehubungan dengan diri seseorang dan orang lain. Karakter yang baik terdiri dari mengetahui hal yang baik, menginginkan hal yang baik, dan melakukan hal yang baik-kebiasaan dalam cara berpikir, kebiasaan dalam hati, dan kebiasaan dalam tindakan. Ketiga hal ini diperlukan untuk mengarahkan suatu kehidupan moral, ketiganya ini membentuk kedewasaan moral. ${ }^{20}$

Pendidikan karakter juga diartikan sebagai upaya penanaman kecerdasan dalam berfikir, penghayatan dalam bentuk sikap, dan pengamalan dalam bentuk perilaku yang sesuai dengan nilai-nilai luhur yang menjadi jati dirinya, diwujudkan dalam interaksi dengan Tuhannya, diri sendiri, masyarakat dan lingkungannya. ${ }^{21}$ Menurut Donie Koesoema pendidikan karakter bersifat liberatif, yaitu usaha yang dilakukan secara individu, baik secara pribadi maupun secara sosial untuk membantu menciptakan lingkungan yang membantu pertumbuhan kebebasannya sebagai individu. ${ }^{22}$

\section{Proses Pembentukan Karakter}

Pembentukan karakter adalah upaya untuk membantu perkembangan jiwa anak baik lahir maupun batin, dari sifat kodratinya menuju kearah peradaban masyarakat dan bangsa secara umum. Pendidikan pembentukan karakter merupakan upaya untuk menumbuhkan dan mengembangkan nilai-nilai yang baik atau positif pada diri anak sesuai dengan etika moral yang berlaku. Anak tidak

\footnotetext{
${ }^{18}$ N. Hartati, dkk, Islam dan Psikologi, (Jakarta: PT. Raja Grafindo Persada, 2001), hlm. 137-138.

${ }^{19}$ Nashir, Pendidikan Karakter Berbasis Agama dan Budaya, (Yogyakarta: Multi Persindo, 2013), hlm. 10-11.

${ }^{20}$ T. Lickona dan J. A. Mendidik untuk Membentuk Karakter bagaimana Sekolah dapat Memberikan Pendidikan tentang Sikap Hormat dan Bertanggungjawab, (Jakarta: Bumi Aksara, 2012), hlm. 81-82.

${ }^{21}$ M. Zubaedi, Desain Pendidikan Karakter. Konsepsi dan aplikasinya dalam lembaga pendidikan, (Jakarta: Pranada Media Group, 2011), hlm. 17.

${ }^{22}$ D. Koesoema, Pendidikan Karakter: strategi mendidik anak di Zaman global, (Jakarta: Grasindo, 2007), hlm. 194.
} 
hanya tahu apa yang seharusnya dikerjakan tetapi juga memahami mengapa hal tersebut dilakukan, sehingga anak akan berperilaku seperti yang diharapkan. ${ }^{23}$

Unsur terpenting dalam pembentukan karakter adalah pikiran, karena pikiran yang di dalamnya terdapat seluruh program yang terbentuk dari pengalaman hidupnya, merupakan pelopor segalanya. Program ini kemudian membentuk sistem kepercayaan yang akhirnya dapat membentuk pola berpikirnya yang bisa mempengaruhi perilakunya. Jika program yang tertanam tersebut sesuai dengan prinsip-prinsip kebenaran universal, maka perilakunyaberjalan selaras dengan hukum alam. Hasilnya, perilaku tersebut membawa ketenangan dan kebahagiaan. Sebaliknya, jika program tersebut tidak sesuaidenganprinsip-prinsip hukum universal, maka perilakunya membawa kerusakan dan menghasilkan penderitaan. Selain itu gen juga sebagai salah satu faktor pembentuk karakter seseorang. ${ }^{24}$

Unsur-unsur lain yang mempengaruhi karakter seseorang menurut Fatchul Mu' in antara lain adalah sikap, emosi, kepercayaan, kebiasaan dan kemauan, serta konsepsidiri. ${ }^{25}$ Adapun penjabaran dari masing-masing hal tersebut adalah sebagai berikut.

a. Sikap

Cerminan karakter seseorang salah satunya dapat dilihat dari sikapnya. Sikap merupakan variabel laten yang mendasari, mengarahkan, dan mempengaruhi perilaku. Sikap tidak identik dengan respons dalam bentuk perilaku, tidak dapat diamati secara langsung tapi dapat disimpulkan dari konsistensi perilaku yang diamati. Sikap juga dapat menjadi alatampuh untuk tindakan positif, atau dapat menjadi penghalang untuk mencapai keutuhan potensi seseorang. Sikap merupakan konsep yang cukup penting, dengan mempelajari sikap akan membantu kita dalam memahami proses kesadaran yang menentukan tindakan nyata dan tindakan yang mungkin dilakukan individu dalam kehidupannya. ${ }^{26}$

b. Emosi

Kata emosi diadopsi dari bahasa Latin yaituemovere (berartiluar dan movere berarti bergerak). Sedangkan dalam bahasa Prancis adalah emouvoir yang artinya kegembiraan. (Mu'in, 2011). Emosi merupakan ungkapan jiwa, segala sesuatu yang sedang manusia rasakan akan tercurahkan dalam luapan emosi, baik itu bahagia, sedih, marah, takut, maupun cinta. Semua hal tersebut merupakan gejala emosi manusia. Emosi tidak selamanya negatif, kita harus senantiasa memelihara dan merawat emosi karena emosi memang harus didorong. Sehingga emosi akan keluar dengan bijaksana. Fungsi jiwa emosi

${ }^{23}$ D. Damayanti, Panduan Implementasi Pendidikan..., hlm. 10. hlm. 17.

${ }^{24}$ A. Majid, dkk, Pendidikan Karakter Perspektif Islam, (Jakarta: PT. Remaja Rosdakarya, 2011),

${ }^{25}$ F. Mu'in, Pendidikan Karakter, konstruksi teori dan praktik, (Yogyakarta: Ar-Ruzz Media, 2011), hlm. 168 .

${ }^{26}$ Ibid., hlm. 171. 
merupakan bagian integral dari pengalaman manusia. Emosi, perasaan, maupun sugesti akan dapat menambah kesenangan maupun kesedihan seseorang. Pengamatan terhadap kegiatan sehari-hari pada kebanyakan individu membawa pada suatu kesimpulan bahwa tindakan-tindakan manusia dipengaruhi oleh dorongan-dorongan dan tekanan-tekanan emosional maupun oleh hasil berpikir dan pertimbangan yang obyektif. ${ }^{27}$

c. Kepercayaan

Kepercayaan merupakan komponen kognitif manusia. Kepercayaan bahwa sesuatu itu "benar" atau "salah" atas dasar bukti, sugesti otoritas, pengalaman, dan intuisisangatlahpentinguntukmembangunwatak dan karakter manusia. Kepercayaan memberikan perspektif bagi manusia dalam memandang kenyataan dan ia memberikan dasar bagi manusia untuk mengambil pilihan serta menentukan keputusan. Kepercayaan dibentuk oleh pengetahuan, karena apa yang kita ketahui membuat kita menentukan pilihan, hal ini karena kita percaya dengan apa yang telah kita ketahui.

d. Kebiasaan dan kemauan

Kebiasaan adalah aspek perilaku manusia yang menetap, berlangsung secara otomatis, serta tidak direncanakan. Kebiasaan merupakan hasil dariperbuatan yang terus menerus dilakukan oleh manusia. Kebiasaan juga memberikan pola perilaku yang dapat diramalkan. Misalnya kita sering melihat si A memberikan bantuan kepada siapa saja yang meminta tolong padanya, maka dapat dikatakan bahwa si A orangnya suka menolong. Sedangkan kemauan merupakan kondisi yang mencerminkan karakter seseorang. Ada orang yang kemauannya keras yang kadang ingin mengalahkan kebiasaan, tetapi ada pula orang yang kemauannya lemah. ${ }^{28}$

e. Konsepsi diri

Konsepsi diri penting karena biasanya orang sukses adalah orang yang sadar bagaimana ia membentuk wataknya. Proses konsepsi diri merupakan proses totalitas, baik sadar maupun tidak sadar tentang bagaimana karakter diri kita dibentuk. Konsepsi diri adalah bagaimana kita harus membangun diri, tahu apa yang diinginkan dan tahu bagaimana menempatkan diridalam kehidupan. $^{29}$

Berdasarkan penjelasan di atas maka dapat dikatakan bahwa karakter seseorang tidak terjadi secara instan akan tetapi melalui proses yang begitu panjang, berawal dari gen kemudian lingkungan keluarga, pergaulan, masyarakat serta pengalaman hidup individu.

\footnotetext{
${ }^{27}$ F. Mu'in, Pendidikan Karakter, konstruksi..., hlm. 176.

${ }^{28}$ Ibid., hlm. 178.

${ }^{29}$ Ibid., hlm. 179.
} 


\section{B. Integrasi Pendidikan Karakter dengan ESQ Learning di Madrasah Ibtidaiyah}

Dunia pendidikan, melalui pemahaman ESQ dapat diperoleh kesadaran bahwa ukuran penilaian tidaklah cukup hanya pada intelektualitas saja, namun yang paling utama adalah unsur spiritualitas yaitu kepercayaan dan kasih sayang (SQ), serta emosionalitas yaitu rendah hati dan santun. Sehingga dengan penerapan konsep ESQ ini mampu memberikan kontribusi terhadap pendidikan karakter yang Islami. Ada beberapa aspek yang dapat memadukan kurikulum yang ada di Madrasah Ibtidaiyah dengan konsep ESQ Learning yaitu:

\section{Ditinjau dari Aspek Tujuan}

Tujuan pendidikan karakter adalah membentuk manusia yang tangguh, kompetitif, berakhlak mulia, bermoral, bertoleran, bergotong royong, berjiwa patriotik, berkembang dinamis, berorientasi ilmu pengetahuan dan teknologi yang semuanya dijiwai oleh iman dan takwa kepada Tuhan Yang Maha Esa berdasarkan Pancasila. (Daryanto, 2013, hal. 44). Kemudian menurut konsep ESQ Learning, pendidikan karakter mempunyai tujuan untuk:

a. Membentuk manusia handal (khairu ummah)

b. Mewujudkan Manusia yang Sukses dan Bahagia

c. Sebagai Formula Membangun Karakter Manusia

Berdasarkan ketiga tujuan di atas dapat dianalisis bahwa sifat manusia yang tangguh, kompetitif, berakhlaq mulia, bermoral, bertoleran, bergotong royong adalah perwujudan dari penjabaran Khairu Ummah. Kemudian untuk mewujudkan manusia yang sukses dan bahagia perlu adanya penyeimbangan antara ilmu pengetahuan yang dimiliki dengan iman dan taqwa kepadaTuhan Yang Maha Esa. Selanjutnya sebagai formula membangun karakter manusia maka diperlukan sikapsikap yang disebutkan di atas yang diimbangi dengan Iman dan Taqwa kepada Tuhan Yang Maha Esa berdasarkan pancasila.

Menurut Ahmad Amin, tujuan etika adalah untuk mempengaruhi dan mendorong kehendak kita, supaya membentuk hidupsuci dan menghasilkan kebaikan dan kesempurnaan, dan memberi faedah kepada sesama manusia. Maka etika itu ialah mendorong kehendak agar berbuat baik. ${ }^{30}$

Kesimpulannya bahwa ada keterkaitan antara tujuan pendidikan karakter di Madrasah Ibtidaiyah secara umum dengan tujuan pendidikan karakter menurut Konsep ESQ Learning. Oleh karena itu, jika pendidikan karakter dengan metode ESQ diterapkan dalam lembaga pendidikan dasar maka akan mewujudkan peserta didik yang mempunyai karakter sesuai dengan tujuan pendidikan karakter yang diharapkan oleh semua kalangan. Dalam kurikulum Madrasah Ibtidaiyah, tujuan pendidikan karakter relevan dengan pembeljaran aqidah akhlaq.

${ }^{30}$ A. Amin, Etika (Ilmu Akhlak), Terj, KH Farid Ma'ruf, Cet. 3, (Jakarta: Bulan Bintang, 1983), 


\section{Ditinjau dari Aspek Isi atau Materi Pendidikan Karakter di Madrasah Ibtidaiyah}

Berdasarkan penjelasan tentang nilai-nilai pendidikan karakter dalam Islam disebutkan bahwa sumber nilai yang berlaku dalam pranata kehidupan manusia adalah nilai Ilahiyah dan Insaniyah. Nilai IIlahiyah dan Insaniyah relevan dengan mata pelajaran agama yang diajarkan dalam kurikulum Madrasah Ibtidaiyah, diantaranya melalui pembelajaran Fiqih, Aqidah Akhlaq, dan Qur'an Hadits.

Adapun penjabaran dari kedua nilai tersebut adalah sebagai berikut:

\section{a. Nilai Ilahiyah}

1) Iman

Dijelaskan dalam konsep ESQ Learning bahwa untuk membangun kecerdasan mental, maka perlu membangun enam prinsip berdasarkan rukun iman, yaitu: (1) Membangun prinsip bintang, (2) Memiliki prinsip Malaikat sehingga kita selalu dipercaya oleh orang lain, (3) Memiliki prinsip kepemimpinan yang akan membimbing kita menjadi pemimpin yang berpengaruh, (4) Menyadariakan pentingnya prinsip pembelajaran yang akan mendorong kepada kemajuan, (5) Mempunyai prinsip masa depan sehingga akan selalu memiliki visi, dan (6) Memiliki prinsip keteraturan sehingga tercipta sistem mental (EQ) dalam ketauhidan. ${ }^{31}$

Menurut Toshihiko Izutsu dalam bukunya Ethico Religious concepts in the Qur'an menyebutkan bahwa: The believer in the true sense of the word as a genuinely pious man, in whose heart the very mention of God's name is enough to arouse an intense sense of awe, and whose whole life is determined by the basic mood of deep earnestness. (Ahmad, 1973, hal. 185).

Berdasarkan pernyataan di atas disebutkan bahwa orang yang beriman dalam arti kata yang sesungguhnya adalah orang yang benar-benar taat, yang hatinya senantiasa menyebut nama Allah sehingga mampu menimbulkan rasa kagum yang sangat kuat, dan yang sepanjang hidupnya ditentukan oleh suasana hati ketaatan yang mendalam.

2) Islam

Selanjutnya setelah seseorang telah memiliki enam prinsip moral tersebut di atas, ke enam prinsip tersebut diwujudkan dalam pelaksanaan pada dimensi fisik, dengan lima pedoman yang dikenal dengan rukun Islam. (1) Memiliki mission statement yang jelas, yaitu dua kalimat Syahadat sebagai tujuan hidup dan komitmen kepada Tuhan, (2) Memiliki sebuah pembangun karakter melalui shalat lima waktu, (3) Memiliki kemampuan pengendalian diri yang dilatih dan disimbolkan dengan puasa, (4) Selanjutnya potensi dikeluarkan melalui zakat dan (5) Haji. ${ }^{32}$ Prinsip dan langkah ini teramat penting, karena akan menghasilkan kecerdasan emosi dan spiritual (ESQ) yang tinggi (Akhlakul Karimah).

${ }^{31}$ A.G. Agustian, Rahasia Sukses Membangun..., hlm. 171.

${ }^{32}$ A. G. Agustian, ESQ The ESQ Way 165 Cet. XX, (Jakarta: Arga,2005), hlm. 255. 
Rukun Islam sebagai pendidikan berfungsi untuk membentuk kepribadian Islam. Bentuk kepribadian itu adalah apa yang diistilahkan dengan taqwa. Taqwa memancarkan kemauan. Kemauan melahirkan laku perbuatan ibadat, yang pelaksanaannya didorong oleh hati. Laku perbuatan ibadah itu disebut amal shaleh. ${ }^{33}$

Perwujudan kasih sayang Allah kepada manusia, Islam mesti disebarkan oleh kaum muslimin dengan cara yang lembut dan penuh kasih sayang juga. ${ }^{34}$ Ihsan adalah kesadaran yang sedalam-dalam nyabahwa Allah senantiasa hadir atau berada bersama kita dimanapun kita berada. ${ }^{35}$ Tujuan Ihsan dalam konsep ESQ tidak sekedar melakukan apa yang diperintahkan oleh-Nya, melainkan bertujuan untuk melakukan semua perbuatan semata-mata demi Allah. Lantaran tidak ada realitas kecuali Yang MahaNyata, maka setiap perbuatan dan pikiran haruslah menuju Yang Maha Nyata (Allah).

3) Taqwa

Menurut Ibnu Katsir, taqwa adalah menjalankan segala perintah Allah, menjauhi segala larangan-Nya, dan hasilnya dijauhkan dari siksa neraka. ${ }^{36} \mathrm{Hal}$ ini berkaitan erat dengan konsep ESQ bahwa format EQ tercipta berdasarka nkesadaran spiritual, serta sesuai dengan suara hati terdalam dari dalam diri manusia.

4) Ikhlas

Ikhlas adalah kesadaran agama yang memperlihatkan kedekatan hubungan seseorang dengan Tuhannya. Menurut Ibnu Athaillah, penulis kitab Hikam, amal perbuatan hanyalah bentuk, sedangkan subtansinya adalah ikhlas. Iniberarti, aktivitas keagamaan tanpa sifat ikhlas adalah sia-sia. ${ }^{37}$ Konsep ESQ untuk membangun karakter salah satunya adalah dengan social strength yaitu perwujudan tanggung jawab sosial seorang individu yang telah memiliki ketangguhan pribadi untuk ikhlas dalam mengeluarkan zakat. Jadi disini, manusia dilatih untuk bersifat ikhlas.

5) Tawakkal

Artinya menyerahkan diri kepada Allah, sedang kita sendiri tidak boleh mengurangi usaha dan tenaga dalam berusaha. ${ }^{38}$ Konsep ESQ dikenal dengan istilah Zero Mind Process yaitu suatu usaha untuk mengungkap belenggubelenggu hati dan mencoba mengidentifikasi belenggu tersebut, sehingga dapat dikenali apakah paradigma tersebut telah menutup suara hati.

${ }^{33}$ S. Gazalba, Asas Agama Islam; pembahasan ilmu dan filsafat tentang rukun Islam, Ihsan, Ikhlas, Taqwa, (Bulan Bintang, 1975), hlm. 21.

${ }^{34}$ A. W. Hasan, Sebuah Pengantar "dalam Machasin, Islam Dinamis, Islam Harmonis, (Yogyakarta: LKIS 2012).

${ }^{35}$ A. Majid, dkk, Pendidikan Karakter Perspektif..., hlm. 93.

${ }^{36}$ Nashir, Pendidikan Karakter Berbasis..., hlm. 69.

${ }^{37}$ A. L. Ismail, Pilar-pilar TaqwaDoktrin, Pemikiran, Himat dan PencerahanSpiritual, (Jakarta: PT. Raja Grafindo Persada, 2009), hlm. 15.

${ }^{38}$ A. Salim, Tauhid, Taqdir dan Tawakkal, (Jakarta: Tinta Mas, 1960), hlm. 24. 
6) Syukur

Yaitu mengerahkan secara total apa yang dimilikinya untuk mengerjakan apa yang paling dicintai Allah. ${ }^{39} 33$ drive suara hati yang terdapat dalam God Spot, mensyukuri menerima segala hal dengan ikhlas adalah wujud ihsan kepada salah satu sifat Allah SWT yaitu asy-Syakuur. Apresiasi syukur seseorang kepada orang lain dapat dilakukan dengan beberapa cara, diantaranya adalah mengucap pujian dan terimakasih serta membalas perbuatan baiknya dengan yang lebih baik atau setimpal.

7) Sabar

Adalah sikap tabah dalam menghadapi segala kepahitan hidup, besar dan kecil, lahir dan batin, fisiologis maupun psikologis, karena keyakinan yang tak tergoyahkan bahwa kita semua berasal dari Allah dan akan kembali kepada-Nya. Antara sabar dan syukur ada keterkaitan seperti keterkaitan antara nikmat dan cobaan. Setiap orang tidak dapat terlepas dari nikmat dan cobaan itu dalam menjalanka nkehidupan di dunia. Kesabaran itu sendiri dibagi menjadi tiga macam. Pertama, sabar dalam ketaatan kepada Allah. Kedua, sabar dari kemaksiatan. Ketiga, sabar ketika mendapat cobaan. Semua itu merupakan gambaran kehidupan. Oleh karenanya, sabara dalah separuh keimanan. ${ }^{40}$ Sabar merupakan wujud ihsan kepada Ash-Shabuur.

b. Nilai Insaniyah

Nilai-nilai pendidikan karakter dalam islam yang perlu kita tanamkan pada anak, maka dalam hal ini peneliti menganalisis keterkaitannnya dalam konsep $E S Q$, hasilnya adalah sebagai berikut:

1) Silaturahmi

Yaitu pertalian cita kasih antara sesama manusia, khususnya antara saudara, kerabat, handai taulan, tetangga dan seterusnya. Cinta kasih membutuhkan atau menuntut kerelaan, kejujuran, kepercayaan, tanggungjawab, dan pengorbanan. Cinta seseorang terhadap sesuatu dipengaruhi oleh kondisi kejiwaan, pengalaman individual, pengalaman sosial, sikap hidup hingga pandangan hidup yang melekat dalam dirinya. ${ }^{41}$ Konsep ESQ terdapatunsur zakat dan haji untuk membangun Social Strength atau ketangguhan sosial. Hasil yang akan kita terima dari hal ini adalah sikap silaturahmi.

2) Al-Ukhuwah

Adalah semangat persaudaraan, lebih-lebih kepada sesama orang-orang yang beriman. Jika dikaitkan dengan konsep ESQ, maka al-ukhuwah termasuk dalam salah satunilai yang dapat membangun social Strength pada dalam diri kita.

448.

${ }^{39}$ S. Hawwa, Tazkiyatun Nafs: Intisari IhyaUlumuddin, (Jakarta: Pena Pundi Aksara, 2007), hlm.

${ }^{40}$ Ibid., hlm. 386.

${ }^{41}$ Nashir, Pendidikan Karakter Berbasis..., hlm. 90. 
3) Al-Musawah

Ialah pandangan bahwa semua manusia, tanpa memandang jenis kelamin, kebangsaan, atau kesukuannya, dan lain-lain, adalah sama dalam harkat dan martabat, sesuai dengankonsep ESQ bahwa kita dituntut untuk melihat semua sudut pandang secara bijaksana berdasarkan suara-suara hati yang bersumber dari Asmaul Husna. ${ }^{42}$

4) Al-'Adalah

Menurut Abu Bakar Jaabir Al-Jazaairy dalam kitabnya Minhajul Muslim dijelaskan bahwa:

Adil ialah melakukan tugas dan kewajiban sebagaimana mestinya, atau meletakkan sesuatu pada tempat dan proporsi yang lunak sebagaimana mestinya. Seorang muslim akan berlaku adil dalam setiap ucapan dan keputusannya, dan prinsip keadilan itu senantiasa menjiwai perilakunya sehingga menjadi budi pekerti baginya. ${ }^{43}$

Berdasarkan konsep ESQ Learning, adil merupakan salah satu dari Spiritual core values yang diambil dari asmaul husna yang harus dijunjung tinggi sebagai bentuk pengabdian manusia kepada sifat Allah Al-'Adl.

5) Husnudzan

Yaitu berbaik sangka kepada sesama manusia, berdasarkan ajaran agama bahwa manusia itu pada asal dan hakikatnya adalah baik, karena diciptakan Allah dan dilahirkan atas dasar fitrah kejadian asal yang suci. Baik sangka menurut Abu Muhammad Al-Mahdawi, adalah meniadakan prasangka buruk. Dalam pergaulan sehari-hari baik sangka menjadi amat penting. Sebab, betapa banyak konflik, permusuhan, bahkan pembunuhan, timbul hanya karena persangkaan yang buruk. ${ }^{44}$

Aplikasi zero mind process, orang yang memiliki prinsip akan lebih mampu melindungi pikirannya. Ia mampu memilih respon positif di tengah lingkungan paling buruk sekalipun. Ia akan tetap berpikir positif dan selalu berprasangka baik pada orang lain.

6) At-Tawadlu'

Adalah sabar dan tetap rendah diri ketika mendapat cacian dari orang lain. Sifat tawadhu' tidak mungkin dapat diraih hanya dengan ilmu, kecuali diiringi dengan perbuatan. ${ }^{45}$ Dalam konsep ESQ dikenal dengan istilah star principle yang memerintahkan kita untuk melakukan segala sesuatu dengan sungguh-sungguh dan sebaik-baiknya karena Allah.

7) Al-Wafa

Ialah tepat janji, salah satu sifat orang yang benar-benar beriman ialah sikap selalu menepati janji bila membuat perjanjian. Agama Islam sangat

\footnotetext{
${ }^{42}$ A. Majid, dkk, Pendidikan Karakter Perspektif..., hlm. 96.

${ }^{43}$ S. A. B. J. Al-Jazsiri, Minhajul Muslim, (Pustaka Al-Kautsar, 2015), hlm. 155.

${ }^{44}$ A. L. Ismail, Pilar-pilar TaqwaDoktrin..., hlm. 107.

${ }^{45}$ S. Hawwa, Tazkiyatun Nafs: Intisari..., hlm. 263.
} 
menghormati perjanjian. Dalam perspektif ini, tepat janji merupakan sikap sekaligus tindakan yang amat terpuji dan merupakan bagian tak terpisahkan dari Iman dan Taqwa. Untuk dapat tepat janji, menurut ulama Mesir kontemporer Muhammad Ghazali, seorang muslim harus memperhatikan dual hal. Pertama, Ia harus selalu ingat dan tidak boleh lupa meski sesaat terhadap semua janjinya. Kedua, Ia harus memiliki tekad yang kuat untuk dapat memenuhi semua janjin yaitu. ${ }^{46}$

Salah satu prinsip untuk membangun konsep ESQ adalah well organized principle, disebutkan bahwa kita harus membuat segala sesuatu dengan teratur dalam suatu sistem, hal ini berarti jika kita dapat menerapkan sikap Al-Wafa niscaya semuanya akan berjalan dengan teratur dan sistematis. Al-Wafa juga merupakan wujud ihsan kepada Al-Muqiit.

8) Insyirah

Merupakan sikap lapang dada, yaitu sikap penuh kesediaan menghargai orang lain dengan pendapat-pendapat dan pandangan-pandangannya. Orang yang bersih hati dan lapang dada adalah orang yang mampu menekan secara maksimal kecenderungan-kecenderungan buruk yang ada dalam dirinya. Sebaliknya, ia juga mampu mengembangkan potensi-potensi baik yang ada dalam dirinya menjadi kualitas moral yang nyata dan aktual dalam kehidupannya. $^{47}$

Hanya orang yang bersih hati dan lapang dada seperti itu mampu dan sanggup mencintai saudaranya seperti mencintai dirinya sendiri. Menurut 33 drive suara hati yang terdapat dalam God Spot, lapang dada merupakan wujud ihsan kepada Al-Waasi'.

9) Al-Amanah

Suatu konsekuensi iman adalah amanah atau penampilan diri yang dapat dipercaya. Orang yang amanah, lisan dan tindakannya sejalan, jika berjanji ditepati, dan apabila diberi kepercayaan dijaga dan ditunaikan dengan sebaik-baiknya. ${ }^{48}$ Sesuai dengan angel principle, dijelaskan bahwa kita dituntut untuk bekerja dengan tulus, ikhlas, jujur, dan amanah seperti yang dilakukan oleh malaikat.

10) Iffah atau ta'affuf

Yaitu sikap penuh harga diri, namun tidak sombong, jadi tetap rendahhati, dan tidak mudah menunjukkan sikap memelas atau iba dengan maksud mengundang belas kasihan orang lain dan mengharapkan pertolongannya.

Menurut terminology akhlaq Islam, usaha manusia untuk membangun kehormatan dan citra diri yang baik sesuai petunjuk Allah dan Rasul-Nya itu dinamai sifat muru'ah. Muru'ah berarti menjaga diri hingga mencapai puncak

\footnotetext{
${ }^{46}$ A. L. Ismail, Pilar-pilar TaqwaDoktrin..., hlm. 142.

${ }^{47}$ S. Hawwa, Tazkiyatun Nafs: Intisari..., hlm. 116.

${ }^{48}$ Nashir, Pendidikan Karakter Berbasis ..., hlm. 76.
} 
kesempurnaannya, sehingga dalam dirinya tak tampak sedikit pun keburukan maupun kekurangan.

Pembangunan sifat muru'ahitu, kata Ibnu Qayyim al-Jauziyah, seseorang harus mampu meningkatkan kualitas moral dan akhlaqnya baik secara internal, horizontal maupun vertical. ${ }^{49}$ Berdasarkan leadership principle diajarkan bahwa untuk menjadi seorang pemimpin, kita harus selalu menjaga tingkah laku, karena hal ini bisa meningkatkan atau menurunkan kepercayaan, dan ini akan berpengaruh pada lingkungan.

11) Qowamiyah

Adalah sikap tidak boros dan tidak perlu kikir dalam menggunakan harta. ${ }^{50}$ Melainkan sedang antara keduanya. Hal ini sesuai dengan vision principle, artinya kitaharus memiliki tujuan dan misi jangka pendek dan jangka panjang. Jadi kita harus bisa mengatur keuangan kita jangan sampai diawal kita menghambur-hamburkan uang tanpa memikirkan masa depan, sehingga akan menyesal dibelakangnya nanti. Qowamiyah juga merupakan wujud dari sikap dermawan yang termasuk wujud ihsan terhadap Al-Barr.

12) Al-Munfiqun

Yaitu sikap kaum beriman yang memiliki kesediaan yang besar untuk menolong sesama manusia, terutama mereka yang kurang beruntung. Hal ini merupakan langkah nyata untuk membangun social strength kita sendiri. Zakat adalah suatu metode untuk membangkitkan dan memunculkan kepermukaan suara hati yang berasal dari sifat mulia Allah SWT. Al-Munfiqun juga merupakan wujud dari ihsan kepada An-Nafi' artinya dimanapun ia berada selalu berguna bagi setiap orang yang membutuhkan pertolongan. ${ }^{51}$

\section{Ditinjau dari aspek strategi pembentukan pendidikan karakter di madrasah}

Berdasarkan pembahasan yang ada di bab II tentang Strategi pelaksanaan pendidikan karakter di sekolah/madrasah dapat dilakukan dengan 4 cara, maka dalam ha ini peneliti menganalisis keterkaitannya dengan konsep ESQ Learning. Adapun analisisnya sebagai berikut:

a. Mengintegrasikan kesetiap mata pelajaran

Berdasarkan konsep ESQ learning dijelaskan bahwa untuk terlepas dari belenggu-belenggu kehidupan, maka kita harus berpegang teguh dengan Asmaul Husna. Pemaksimalan pembentukan karakter peserta didik di sekolah/madrasah, perlu adanya pembiasaan secara terus-menerus dalam penanaman pendidikan karakter. Salah satunya adalah dengan mengintegrasikan pendidikan karakter kesetiap mata pelajaran. Pada kurikulum Madrasah Ibtidaiyah khususnya mata pelajaran Aqidah Akhlaq di sebutkan

\footnotetext{
${ }^{49}$ A. L. Ismail, Pilar-pilar TaqwaDoktrin..., hlm. 100.

${ }^{50}$ A. Majid, dkk, Pendidikan Karakter Perspektif..., hlm. 98.

${ }^{51}$ Ibid., hlm. 96.
} 
bahwa salah satu kompetensi dasarnya adalah mengenal sifat-sifat Allah melalui Asmaul Husna. ${ }^{52}$

b. Pengembangan budaya sekolah

Berdasarkan konsep ESQ learning, untuk mengembangkan budaya sekolah, maka perlu adanya penguatan zero mind process untuk menanamkan 6 rukun iman, 5 rukun Islam, dan Ihsan. Pembentukan budaya sekolah berbasis pendidikan karakter dapat dilakukan melalui keteladanan, kegiatan spontan saat guru mengetahui perilaku siswa yang kurang baik, cerita/kisah teladan, pengondisian, dan kegiatan rutin.

c. Melalui kegiatan ekstrakulikuler

Berdasarkan Kurikulum 2013 salah satu kegiatan ekstrakurikuler yang wajib dilaksanakan dalam lembaga pendidikan adalah kegiatan kepramukaan. Dalam kegiatan kepramukaan ada pedoman yang dijadikan sebagai prinsip dalam menjalankan kegiatan kepramukaanya itu darma pramuka. Darma pramuka terdiri dari 10 poin yang berisi nilai-nilai pendidikan karakter yang harus dimiliki oleh seorang anggota pramuka. Menurut analisis peneliti, 10 poin yang tertuang dalam darma pramuka tersebut ada kaitannya dengan nilai dasar dalam konsep ESQ yang tertuang dalam 7 Spiritual Core Values.

d. Kegiatan keseharian di rumah

Demi terciptanya karakter yang baik pada diri peserta didik, maka sekolah perlu melibatkan keluarga yang ada di rumah. Peran serta keluarga dalam membimbing anak-anaknya sangat diperlukan, karena kedekatan emosional mereka lebih mendalam dari pada di lingkungan sekolah. Maka dari itu, keluarga juga perlu menanamkan konsep ESQ learning untuk mendukung pendidikan karakter yang ada di sekolah. Keluarga juga perlu mengawasi anak, agar tidak terjerumus ke hal-hal yang negative yang dapat merusak karakter baik yang sudah ditanamkan di sekolah/madrasah.

\section{Ditinjau dari Aspek Evaluasi dalam Pendidikan Karakter}

Mengukur tingkat keberhasilan pelaksanaan pendidikan karakter di satuan pendidikan dilakukan melalui berbagai program penilaian dengan membandingkan kondisi awaldengan pencapaian dalam waktu tertentu. Penilaian keberhasilan tersebut, dalam konsep ESQ learning dapat dilihat dari hasil capaian seseorang dalam mewujudkan pendidikan karakter yang sudah diterima oleh anak didik dalam diri mereka. Sebagaimana dijelaskan pada bab sebelumnya bahwa tahan-tahapan dalam pembentukan karakter berdasarkan konsep ESQ adalah pembentukan Mental Building, personal strenght, dan social strenght yaitu sebagai berikut:

1. Pembentukan Mental Building

Pembentukan mental building, untuk dapat mengetahui keberhasilan peserta didik dalam mencapai hal ini, maka ada beberapa evaluasi yang bisa dijadikan pedoman yaitu:

\footnotetext{
${ }^{52}$ Permenag No. 921,th. 2013.
} 
a. Mengenali keadaan diri sendiri sebelum bertindak, ketika menghadapi sebuah masalah atau peluang.

b. Selalu menerapkan kecerdasan spiritual yang dimiliki dalam melakukan aktivitas sehari-hari.

c. Memiliki tingkat loyalitas yang tinggi, komitmen yang kuat

d. Memiliki kebiasaan untuk mengawali dan memberi, suka menolong dan memiliki sikap saling percaya.

e. Ketika menjadi seorang pemimpin, selalu mencintai dan memberi perhatian kepada orang lain. Memiliki integritas yang kuat serta memimpin dengan berlandaskan suara hati yang fitrah.

f. Memiliki kebiasaan membaca situasi dengan cermat, selalu mengevaluasi pemikirannya kembali.

g. Selalu berorientasi pada tujuan akhir disetiap langkah yang dibuat.

h. Mengoptimalkan setiap langkah dengan sungguh-sungguh.

i. Yakin akan adanya hari kemudian, sehingga memiliki kendali diri dan sosial, memiliki kepastian akan masa depan dan ketenangan batiniah yang tinggi. ${ }^{53}$

2. Pembentukan Personal Strength

Pembentukan personal strength, untuk dapat mengetahui keberhasilan peserta didik dalam mencapai halni, maka ada beberapa evaluasi yang bisa dijadikan pedoman yaitu:

a. Penetapan misi kehidupan

b. Menanamkan komitmen pengabdian hanya kepada Allah SWT.

c. Kedisiplinan dalam bertindak

d. Melatih kesabaran

e. Menegakkan 7 nilai dasar dalam kegiatan keseharian yaitu: jujur, tanggung jawab, visoner, disiplin, kerjasama, adil dan peduli.

3. Pembentukan Social Strength

Pembentukan social strength, untuk dapat mengetahui keberhasilan peserta didik dalam mencapai hal ini, maka ada beberapa evaluasi yang bisa dijadikan pedoman yaitu: Selalu berlandaskan sikap empati, kepercayaan, sikap kooperatif, keterbukaan, serta kredibilitas.

\section{KESIMPULAN}

Berdasarkan uraian dari keseluruhan pembahasan dan analisis dalam penelitian ini, maka penulis dapat mengambil kesimpulan sesuai dengan rumusan masalah yang telah diuraikan sebagai berikut:

1. Konsep pendidikan karakter di Madrasah Ibtidaiyah sama dengan pendidikan akhlak, yakni pendidikan yang bertujuan untuk membentuk perilaku manusia sesuai dengan ajaran Islam, berlandaskan al-Qur'an dan Hadits. Pendidikan karakter yang ditanamkan dalam pendidikan Islam adalah penciptaan fitrah siswa yang berakhlaqul karimah, karena inti dari Islam adalah terciptanya akhlaqul karimah,

${ }^{53}$ A. G. Agustian, ESQ The ESQ ..., hlm. 255. 
jika akhlaqnya hilang berarti gagal tujuan ajaran-ajaran agama Islam. Beberapa hikmah yang dapat diraih apabila pendidikan akhlaq ditanamkan sejak dini antara lain: Pertama, pendidikan karakter mewujudkan kemajuan rohani, Kedua, pendidikan karakter menuntun kebaikan. Ketiga, pendidikan karakter mewujudkan kesempurnaan iman. Keempat, pendidikan karakter memberikan keutamaan hidup di dunia dan kebahagiaan di hari kemudian. Kelima, pendidikan karakter akan membawa kepada kerukunan rumah tangga, pergaulan di masyarakat dan pergaulan umum.

2. Berdasarkan konsep ESQ learning, maka nilai-nilai pendidikan karakter relevan dengan pendidikan karakter yang ada di Madrasah Ibtidaiyah, hal ini ditunjukkan bahwa terdapat pada 6 rukun Iman, 5 rukun Islam dan Ihsan yang masing-masing terkandung dalam sumber nilai yang berlaku dalam pranata kehidupan manusia, yaitu nilai Ilahiyah dan Insaniyah. Nilai Ilahiyah terdiri dari Iman, Islam, taqwa, ikhlas, tawakkal, syukur dan sabar. Adapun nilai Insaniyah terdiri dari silaturahmi, Al-ukhuwah, Al-musawah, Al adalah, husnudzan, at tawadlu', al wafa, insyirah, al amanah, iffah, qowamiyah, al munfiqun. Dalam konsep ESQ diajarkan prinsipprinsip yang diambil dari rukun iman dan rukun Islam untuk membentuk kepribadian seseorang, kemudian setelah melaksanakan dari ajaran Islam tersebut, maka ia harus meneladani dan mengaplikasikan sifat-sifat Allah yang terangkum dalam Asmaul Husna sehingga akan menghasilkan manusia paripurna (insan kamil) yang memiliki kecerdasan emosional dan spiritual yang tinggi.

\section{DAFTAR PUSTAKA}

Agustian, A. G. (2001). Rahasia sukses membangun kecerdasan emosi dan spiritual, ESQ (Emotional Spiritual Quotient): berdasarkan 6 rukun Iman dan 5 rukun Islam. Jakarta: Arga Wijaya Persada.

Agustian, A. G. (2005). ESQ The ESQ Way 165 Cet. XX, Jakarta. Arga.

Ahmad, A. (1973). Toshihiko Izutsu, Ethico-Religious Concepts in the Qur'an (Book Review). International Journal of Comparative Sociology, 14, 288.

Al-Jazairi, S. A. B. J. (2015). Minhajul Muslim. Pustaka Al-Kautsar.

Amin, A. (1983). Etika (Ilmu Akhlak), Terj, KH Farid Ma'ruf, Cet. 3. Jakarta. Bulan Bintang.

Auerbach, C., \& Silverstein, L. B. (2003). Qualitative data: An introduction to coding and analysis (Vol. 21). NYU press.

Damayanti, D. (2014). Panduan Implementasi Pendidikan Karakter di Sekolah. Yogyakarta. Araska, 97.

Daryanto, S. D. (2013). Implementasi Pendidikan Karakter di Sekolah. Yogyakarta. Gava Media.

Emzir, A. D. (2011). Metodologi Penelitian Kualitatif. Jakarta. Rajawali Pers.

Gazalba, S. (1975). Asas agama Islam; pembahasan ilmu dan filsafat tentang rukun Islam, ihsan, ikhlas, taqwa. Bulan Bintang.

Hartati, N. dkk. (2001). Islam dan Psikologi, Jakarta. PT. Raja Grafindo Persada.

Hasan, A. W. (2012). sebuah pengantar" dalam Machasin, Islam Dinamis, Islam Harmonis. Yogyakarta. LKIS.

Hawwa, S. (2007). Tazkiyatun Nafs: Intisari Ihya Ulumuddin. Jakarta. Pena Pundi 
Aksara.

Ismail, A. I. (2009). Pilar-Pilar Takwa Doktrin, Pemikiran, Hikmat, dan Pencerahan Spiritual. Jakarta: PT. Raja Grafindo Persada.

Koesoema, D. (2007). Pendidikan Karakter: strategi mendidik anak di zaman global. Jakarta. PT. Raja Grafindo Persada.

Lexy, J. M. (2002). Metodologi penelitian kualitatif. Bandung. Remaja Rosdakarya.

Lickona, T. (2012). Educating for character: Mendidik untuk membentuk karakter. Jakarta. Bumi Aksara.

Lickona, T. (2013). Pendidikan karakter panduan lengkap mendidik siswa menjadi pintar dan baik.

Lickona, T., \& Wamaungo, J. A. (2012). Mendidik untuk membentuk karakter: bagaimana sekolah dapat memberikan pendidikan tentang sikap hormat dan bertanggungjawab. Jakarta. Bumi Aksara.

Majid, A., Wardan, A. S., \& Andayani, D. (2011). Pendidikan karakter perspektif Islam. Jakarta. PT. Remaja Rosdakarya.

Moleong, L. J. (2007). Metodologi Penelitian Kualitatif Edisi Revisi. Bandung. PT. Remaja Rosdakarya.

Mu'in, F. (2011). Pendidikan Karakter, Konstruksi Teori Dan Prakatik. Yogyakarta. Ar-Ruzz Madia.

Nashir, H. (2013). Pendidikan Karakter Berbasis Agama Dan Budaya. Yogyakarta. Multi Presindo.

Nomor, P. M. A. R. I. (n.d.). 912 Tahun 2013 Tentang Kurikulum Madrasah 2013 mata pelajaran Pendidikan Agama Islam dan bahasa Arab. 2013. Jakarta. Berita Negara Republik Indonesia.

Salim, A. (1960). Tauhid, Taqdir dan Tawakkal. Jakarta. Tinta Mas.

Soewadji, J. (2012). Pengantar metodologi penelitian. Jakarta. Mitra Wacana Media.

Sugiono, S. (2013). Metode Penelitian Kualitatif. Bandung. Alfabeta.

Suharsimi, A. (2006). Prosedur Penelitian Suatu Pendekatan Praktik. Jakarta. Rineka Cipta.

Wiyani, N. A. (2013). Membumikan Pendidikan Karakter di SD; Konsep, Praktik dan Strategi. Jogjakarta. Ar-Ruzz Media.

Zed, M. (2004). Metode peneletian kepustakaan. Yayasan Obor Indonesia.

Zubaedi, M. (2011). Desain Pendidikan karakter: konsepsi dan aplikasinya dalam lembaga pendidikan. Jakarta. Pranada Media Grup. 